\title{
Diagnostic criteria and follow-up in neuroendocrine cell hyperplasia of infancy: a case series*
}

\author{
Critérios diagnósticos e seguimento em hiperplasia de células \\ neuroendócrinas do lactente: uma série de casos
}

\author{
Vivianne Calheiros Chaves Gomes, Mara Cristina Coelho Silva, José Holanda Maia Filho, \\ Pedro Daltro, Simone Gusmão Ramos, Alan S. Brody, Edson Marchiori
}

\begin{abstract}
Objective: Neuroendocrine cell hyperplasia of infancy (NEHI) is a form of childhood interstitial lung disease characterized by tachypnea, retractions, crackles, and hypoxia. The aim of this study was to report and discuss the clinical, imaging, and histopathological findings in a series of NEHI cases at a tertiary pediatric hospital, with an emphasis on diagnostic criteria and clinical outcomes. Methods: Between 2003 and 2011, 12 full-term infants were diagnosed with NEHI, based on clinical and tomographic findings. Those infants were followed for 1-91 months. Four infants were biopsied, and the histopathological specimens were stained with bombesin antibody. Results: In this case series, symptoms appeared at birth in 6 infants and by 3 months of age in the remaining 6 . $1 n$ all of the cases, NEHI was associated with acute respiratory infection. The most common initial chest HRCT findings were ground-glass opacities that were in the middle lobe/lingula in 12 patients and in other medullary areas in 10. Air trapping was the second most common finding, being observed in 7 patients. Follow-up HRCT scans (performed in 10 patients) revealed normal results in 1 patient and improvement in 9. The biopsy findings were nonspecific, and the staining was positive for bombesin in all samples. Confirmation of NEHI was primarily based on clinical and tomographic findings. Symptoms improved during the follow-up period (mean, 41 months). A clinical cure was achieved in 4 patients. Conclusions: In this sample of patients, the diagnosis of NEHI was made on the basis of the clinical and tomographic findings, independent of the lung biopsy results. Most of the patients showed clinical improvement and persistent tomographic changes during the follow-up period, regardless of the initial severity of the disease or type of treatment.
\end{abstract} Keywords: Lung diseases, interstitial/diagnosis; Lung diseases, interstitial/treatment; Tomography, X-ray computed.

\section{Resumo}

Objetivo: A hiperplasia de células neuroendócrinas do lactente (HCNEL) é uma forma de doença pulmonar intersticial da infância caracterizada por taquipneia, retrações, estertores e hipóxia. 0 objetivo deste estudo foi descrever e discutir os achados clínicos, histopatológicos e de imagem em uma série de casos de HCNEL em um hospital pediátrico terciário, enfatizando critérios de diagnóstico e desfechos clínicos. Métodos: Entre 2003 e 2011, 12 lactentes nascidos a termo foram diagnosticados com HCNEL, com base em critérios clínico-tomográficos e acompanhados por 1-91 meses. Quatro lactentes foram submetidos a biopsia pulmonar, e as amostras histopatológicas foram coradas com anticorpo para bombesina. Resultados: Nesta série de casos, os sintomas surgiram ao nascimento em 6 lactentes e em até 3 meses de idade nos outros 6. Em todos os casos, HCNEL estava associada com infecção respiratória aguda. Os achados iniciais em TCAR de tórax foram opacidades em vidro fosco em lobo médio e língula, em 12 pacientes, e em outras regiões medulares, em 10. 0 aprisionamento aéreo foi o segundo achado mais frequente, em 7 pacientes. As TCAR de controle (realizadas em 10 pacientes) revelaram resultados normais (em 1) e melhorias (em 9). Os achados de biopsia foram inespecíficos, e os resultados para bombesina foram positivos em todas as amostras. A confirmação de HCNEL baseou-se principalmente em achados clínico-tomográficos. Os sintomas melhoraram durante o seguimento (média, 41 meses). Quatro pacientes apresentaram cura clínica. Conclusões: Os achados clínico-tomográficos permitiram o diagnóstico de HCNEL nesta série de pacientes, independentemente dos resultados de biopsia pulmonar. A maioria mostrou melhora clínica e persistência das alterações tomográficas durante o seguimento, independentemente da gravidade inicial da doença ou do tipo de tratamento.

Descritores: Doenças pulmonares intersticiais/diagnóstico; Doenças pulmonares intersticiais/terapia; Tomografia computadorizada por raios X.

\footnotetext{
* Study carried out at the Hospital Infantil Albert Sabin, Fortaleza, Brazil.

Correspondence to: Vivianne Calheiros Chaves Gomes. Rua Desembargador Leite Albuquerque, 1060, apto. 1100, Aldeota, CEP 60150-150, Fortaleza, CE, Brasil.
}

Tel. 5585 3261-1578. Fax: 5585 3261-1578. E-mail: vccgomes@terra.com.br

Financial support: None.

Submitted: 11 March 2013. Accepted, after review: 6 September 2013. 


\section{Introduction}

In 2005, Deterding et al. ${ }^{(1)}$ described neuroendocrine cell hyperplasia of infancy (NEHI) in a study including 15 infants with symptoms of interstitial lung disease (ILD), such as persistent tachypnea, retractions, hypoxemia, and crackles in the first year of life. The same authors had previously used the term persistent tachypnea of infancy for this condition. ${ }^{(2)}$ Lung biopsies of the 15 infants showed minimal and nonspecific changes, despite prominent clinical symptoms. The only specific histopathological finding was an increase in clear cells in the distal airways, representing pulmonary neuroendocrine cells (PNECs), and this finding was confirmed by immunohistochemistry with bombesin antibody staining. ${ }^{(1)}$

PNECs are granular epithelial cells distributed in the conducting airways. They produce vasoactive substances (bombesin, calcitonin, and serotonin) that can cause bronchoconstriction, vasoactivity, epithelial differentiation, and proliferation of adjacent mesenchymal cells (smooth muscle cells and fibroblasts). ${ }^{(1,3)}$ PNECs are numerous in the fetal and neonatal lung; however, their number decreases markedly in the first year of life. ${ }^{(1)}$ These cells have complex functions and are involved in the differentiation and maturation of the fetal lung, neonatal adaptation, lung regeneration, and carcinogenesis. ${ }^{(3)}$ PNEC hyperplasia has been reported in a variety of pediatric pulmonary disorders, as well as in adults; however, the significance of PNEC hyperplasia and the mechanisms involved are unknown. ${ }^{(3,4)}$

Fan et al. ${ }^{(5)}$ recently classified NEHl as a unique form of ILD in infants. In 2007, Deutsch et al. ${ }^{(6)}$ proposed a new classification system for diffuse lung diseases in children under 2 years of age. Their multicenter study was conducted in North America and described 18 new cases of NEHl with clinical and histopathological findings similar to those of the original series.

NEHI has a characteristic clinical and tomographic presentation. Clinically, infants with NEHI present tachypnea, retractions, hypoxemia, and crackles. Chest HRCT shows a characteristic pattern of ground-glass opacity (GGO) in the central regions of the lungs, especially in the middle lobe and lingula, as well as air trapping. ${ }^{(7,8)}$ Recently, some centers have used the term "NEHI syndrome" to diagnose this entity, using only clinical and tomographic criteria. ${ }^{(9)}$ The purpose of the present study was to report and discuss the clinical, imaging, and histopathological findings in a series of $\mathrm{NEHI}$ cases at a tertiary pediatric hospital with an emphasis on diagnostic criteria and clinical outcomes.

\section{Methods}

A series of 12 infants with NEHI, diagnosed by clinical and HRCT criteria or histopathological examination of lung tissue, were followed between March of 2003 and April of 2011. The infants attended a tertiary-level hospital (Hospital Infantil Albert Sabin) in the city of Fortaleza, Brazil. The study was approved by the research ethics committee of the hospital (Protocol no. 068/2010). The parents or guardians of the infants gave written informed consent.

In order to diagnose cases of NEHI, we used a standardized protocol for children under 2 years of age with clinical suspicion of childhood ILD (chlLD). The chlLD syndrome requires the presence of at least three of the four following criteria: respiratory symptoms (cough, rapid or difficult breathing, or exercise intolerance); signs (tachypnea at rest, adventitious sounds, retractions, clubbing, failure to thrive, or respiratory failure); hypoxemia; and diffuse abnormalities on chest X-rays or CT scans..$^{(5,10)}$ We excluded all of the children with ILD of a known cause or associated with systemic diseases.

The criteria for the diagnosis of NEHI were the presence of persistent tachypnea, retractions, crackles, low oxygen saturations, and HRCT findings consisting of GGO, especially in the middle lobe and lingula, associated with air trapping. ${ }^{(9,10)}$

The standardized protocol included the following variables: sex, neonatal condition, history of environmental exposure/family history, age at symptom onset, precipitating factors, initial signs and symptoms, supplemental oxygen use, histopathological findings, imaging findings, treatment, disease progression, and duration of follow-up.

All of the patients underwent a complete evaluation, which included blood count, blood gas analysis, transcutaneous oximetry (at rest, during exercise, and during sleep), echocardiography with indirect measurement of pulmonary arterial pressure, measurement of serum immunoglobulin levels, sweat test, upper gastrointestinal series, serological tests for viral infections, and chest imaging (X-ray 
and HRCT). All of the infants were submitted to imaging tests upon diagnosis, and 10 infants had additional HRCT scans taken during follow-up visits. Regarding HRCT scans, a sequential technique with a low dose protocol $(120 \mathrm{kV}$, $40 \mathrm{mAs})$ was used. All of the patients were sedated with $10 \%$ chloral hydrate $(1 \mathrm{~mL} / 3 \mathrm{~kg}$ of body weight), and images were obtained during quiet breathing. During the inspiratory phase, six to ten 1 -mm slices were obtained with the patient in the supine position. From 2006 onward, CT scans in the lateral position on both sides during the expiratory phase were also obtained, as described by Lucaya et al. ${ }^{(11)}$ Four to six images were obtained, resulting in twelve $1-\mathrm{mm}$ slices with a $10-20-\mathrm{mm}$ range. All images were reviewed in consensus by two experienced pediatric radiologists.

Initial and follow-up CT scans were used in order to identify the number of lobes involved, the lingula being considered as a separate lobe. The HRCT scans were assessed for the presence, distribution, and extension of GGOs and air trapping. The criteria for these findings are defined in the Fleischner Society Glossary of Terms. ${ }^{(12)}$ Any other lung abnormalities were also investigated. The presence of air trapping was assessed only on expiratory HRCT images. The first four patients in the present series underwent chest HRCT-guided open lung biopsy with the consent of a legal guardian. Immunohistochemistry with bombesin antibody staining was performed. Pulmonary function tests were performed in cooperative patients older than 6 years of age.

The presence of GGO in the central regions of the lungs involving at least four lung lobes (including middle lobe and lingula) and associated with air trapping was considered a characteristic tomographic finding of NEHI. ${ }^{(9)}$ Infants who presented involvement of fewer than four lung lobes were diagnosed by lung biopsy.

\section{Results}

All of the infants ( 8 males and 4 females) were born at full term. No infant had a family history of ILD, a history of environmental exposure, or a history of continued exposure to high altitude. Six patients experienced respiratory symptoms during the neonatal period that did not require oxygen therapy, and their clinical deterioration, with increased work of breathing and oxygen requirement, developed at 2-6 months of life following an episode of acute respiratory infection (ARI). In this context, ARI refers to the first episode of a probable viral infection in the upper airways. In the remaining 6 patients, ILD symptoms started at 1-3 months of age following an episode of ARI. Among the 12 infants, 8 were referred to the outpatient clinic for clarification of persistent tachypnea with a previous diagnosis of acute viral bronchiolitis, asthma, pneumonia, gastroesophageal reflux, or heart disease, and 4 were hospitalized upon diagnosis due to respiratory distress requiring oxygen therapy. All of the patients presented with tachypnea and chest retractions disproportionate to $X$-ray findings, but no toxemia. Only 1 infant presented with cough, although this was not a prominent complaint. Crackles were present in 7 patients and were transient in most of these patients. Wheezing was absent in all infants. Hypoxemia was present in only 5 infants, with no pulmonary hypertension or clubbing at baseline. Feeding problems (choking or regurgitation) were present in 7 patients; however, diagnostic tests revealed no aspiration syndrome in order to justify the respiratory symptoms. Among the 12 infants, 6 had difficulty in gaining weight. The anteroposterior diameter of the chest was increased (best identified from the sixth month of life onward) in 8 patients. Pectus excavatum was identified in only 1 infant. The main characteristics of the patients are summarized in Table 1.

Chest X-rays showed lung hyperinflation in 9 patients; perihilar opacities, in 5; and increased bronchovascular markings in the perihilar region, in 1. Initial HRCT scans showed GGO in the central regions of the lungs (including middle lobe and lingula) in all cases, as well as in other central regions, in 11 cases. Peripheral regions were affected in 5 patients. Air trapping, especially in the lower lobes, was the second most frequent finding, in 7 patients. Two to six lobes were affected in each patient, five or more lobes being affected in 10 cases. The only CT changes found in this series were GGO and air trapping (Figure 1). The main HRCT findings are summarized in Table 2. Mean age at initial HRCT examination was 9.4 months (range, 6-16 months). The mean interval between the first outpatient consultation and the first HRCT examination was 1 month. 


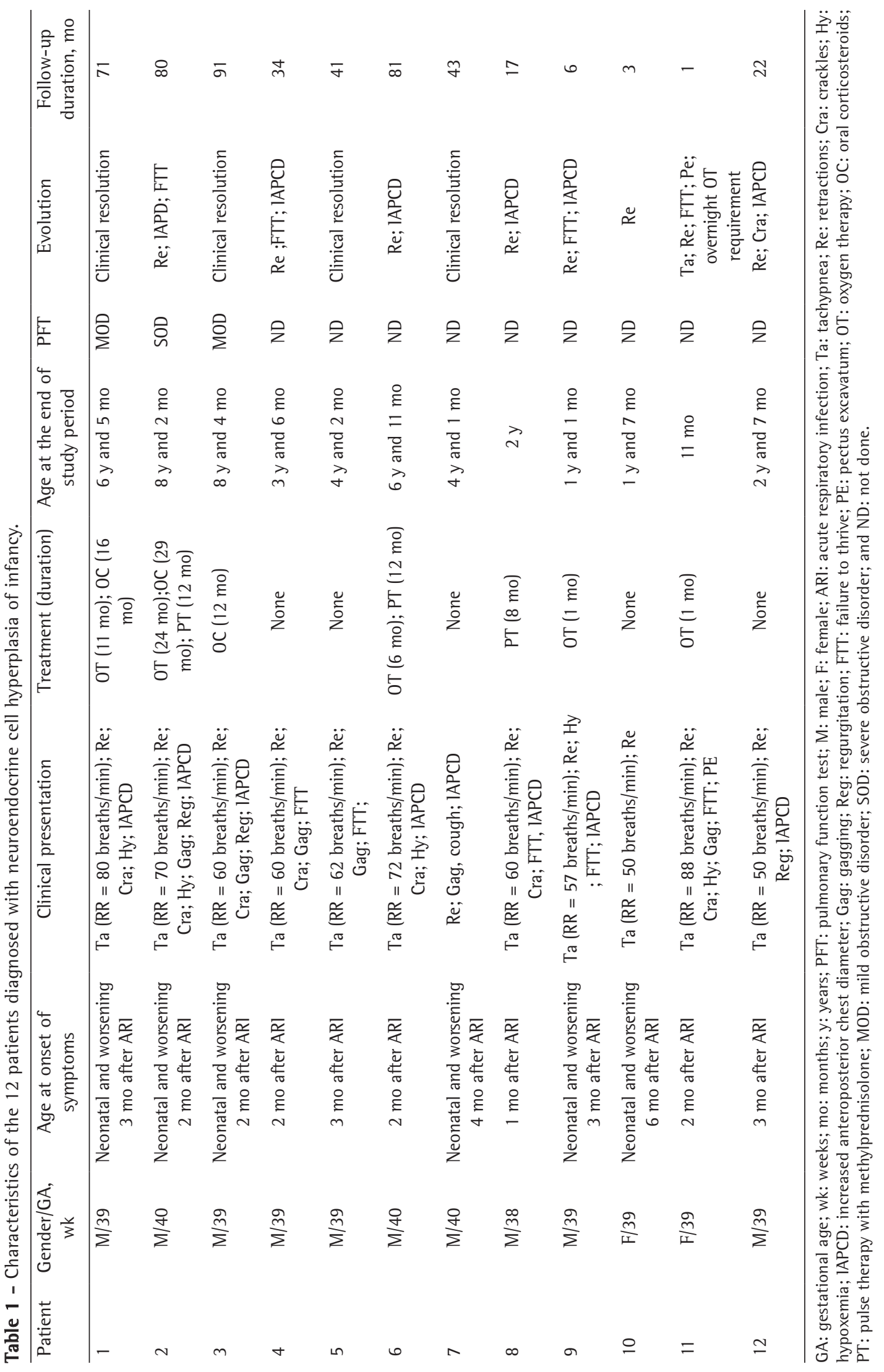



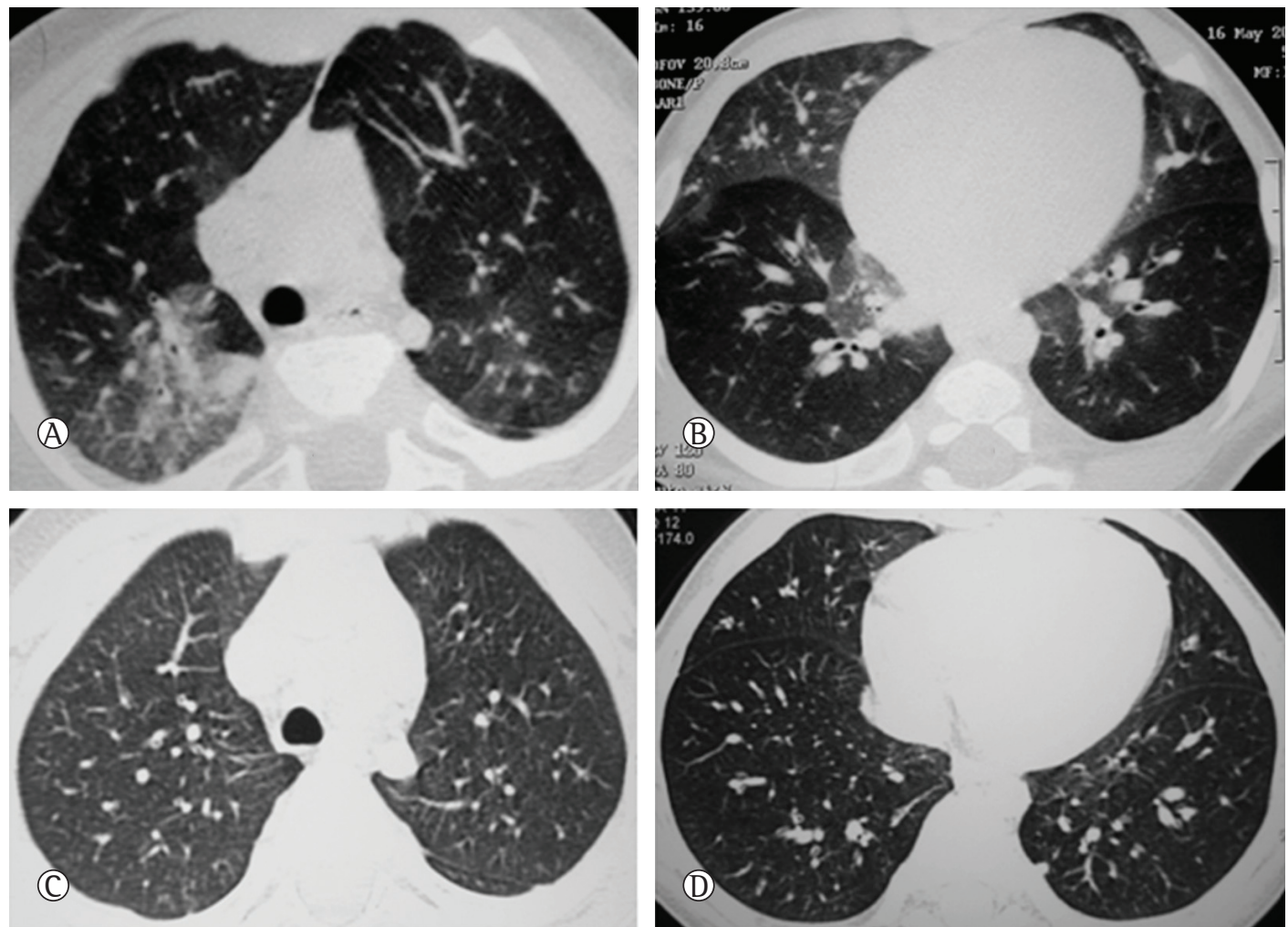

Figure 1 - In A and B, HRCT scans of a 5-month-old patient showing mosaic attenuation with geographic ground-glass opacities in the posteromedial upper lobes, middle lobe, lingula, and lower lobes. In C and D, follow-up HRCT scans of the same patient four years later showing that the lungs were normal.

The first 4 patients included in the present series underwent lung biopsy, 3 of whom under 10 months of age and 1 of whom at 51 months. The histopathological findings demonstrated normal alveolar structures without any fibrosis. Slightly enlarged peribronchial lymphocyte aggregates were seen in 3 cases. Immunohistochemistry showed a significant number of bombesin-positive cells in the walls of the small airways consistent with neuroendocrine cells.

Most of our cases $(n=7)$ required no oxygen therapy. Only 2 of the 5 hypoxemic infants required continuous oxygen therapy. One patient required overnight oxygen therapy for 24 months. Three infants received oxygen therapy only overnight or during episodes of ARI. Therapy was performed with oxygen to maintain oxygen saturation greater than $92 \%$, measured by transcutaneous oximetry. Five infants were treated with systemic corticosteroids: oral corticosteroids, in 2; monthly methylprednisolone pulse therapy, in 2; and oral corticosteroids and hydroxychloroquine plus methylprednisolone pulse therapy, in 1 (the patient with the most severe disease in the series).
The mean duration of systemic corticosteroid therapy was 15 months (range, 8-29 months). Prior use of bronchodilators and oral corticosteroids was common; however, clinical response was unsatisfactory. Five infants received no specific treatment except for antireflux medication in order to mitigate regurgitation or vomiting.

All of the infants showed progressive clinical improvement and, after 24 months of age, none depended on oxygen therapy. No patient was hospitalized due to respiratory problems or recurrent wheezing. During the follow-up period, none of the patients experienced pulmonary hypertension or clubbing. Most patients showed persistent retractions, resolution of crackles, and reduction in anteroposterior chest diameter with age. Difficulty in gaining weight persisted in 4 of the 6 infants with that initial complaint. Pulmonary function tests (performed in 3 patients) showed mild obstructive respiratory pattern in 2 and severe obstructive respiratory pattern in 1 patient with a major thoracic deformity. Follow-up HRCT scans performed in 10 patients showed 
persistence of GG0 in 9 patients, mainly in the middle lobe and lingula, and air trapping, in 5 patients, predominantly in the lower lobes. The number of affected lobes decreased during the follow-up period, and changes were less intense overall (Figure 2 and Table 2). The mean time from initial HRCT to follow-up HRCT examinations was 36 months (range, 4-72 months). Complete tomographic and clinical resolution was achieved in 1 patient, whose HRCT scans displayed initial involvement of the lingula and right middle lobe and areas of air trapping. Three patients had complete clinical resolution, despite still showing functional and CT alterations. Clinical and CT improvement was not correlated with any type of treatment, although the most symptomatic cases showed a greater number of affected lobes on initial CT scans. Only 1 infant, who presented with respiratory dysfunction at 2 months and who was 11 months old at the end of the study period, continued to receive oxygen therapy during sleep due to young age and relatively recent diagnosis. All of the patients were alive at the end of the study period (mean age, 50 months; range, 11-100 months) and showed improvement of the thoracic deformity (increased anteroposterior chest diameter). Eight patients continued to show mild respiratory dysfunction, and 4 patients achieved clinical cure. No patient in our series was lost to follow-up. The mean duration of the follow-up period was 41 months (range, 1-91 months).

Table 2 - HRCT findings in the 12 patients diagnosed with neuroendocrine cell hyperplasia of infancy.

\begin{tabular}{|c|c|c|}
\hline \multirow[t]{3}{*}{ HRCT findings } & \multicolumn{2}{|c|}{ Patients, n/N } \\
\hline & Initial HRCT & $\begin{array}{c}\text { Follow-up } \\
\text { HRCT }\end{array}$ \\
\hline & $(N=12)$ & $(n=10)$ \\
\hline Central GG0 & 12/12 (RML, L) & 9/10 (RML, L) \\
\hline Peripheral GG0 & $5 / 12$ & $0 / 10$ \\
\hline $\begin{array}{l}\text { Air trapping } \\
\text { Number of } \\
\text { affected lobes }\end{array}$ & $7 / 12$ & $5 / 10$ \\
\hline$<2$ & $0 / 12$ & $\begin{array}{c}1 / 10 \\
\text { (normal HRCT) }\end{array}$ \\
\hline $2-4$ & $2 / 12$ & $5 / 10$ \\
\hline $5-6$ & $10 / 12$ & $4 / 10$ \\
\hline
\end{tabular}

GGO: ground-glass opacities; RML: right middle lobe; and L: lingula.

\section{Discussion}

In the last decade, NEHI was described as an ILD that exclusively affected infants, with characteristic clinical findings (tachypnea, retractions, hypoxemia, and crackles) and tomographic findings (GGO in the central regions of the lungs, especially in the middle lobe and lingula, and air trapping), and good prognosis ${ }^{(9,10,13)}$; similar results were found in our case series, only differing in the need for oxygen therapy, which was lower than in previous reports.

Previous reports of NEHI also found a male predominance, and most subjects were born full term and presented the first symptoms by 15 months of age..$^{(1,6,14)}$ Similarly, all infants in the present series were born full term and most were male; however, 50\% presented symptoms in the neonatal period, showing an earlier onset of the disease in relation to other series. The early presentation of the illness observed in the present series suggests that a possible genetic cause is involved in its pathogenesis, since familial cases have been described in the literature. ${ }^{(14)}$ Disease symptoms were associated with or aggravated by ARI. In fact, ARI might have precipitated the onset of NEHI or aggravated existing symptoms. It is possible that NEHI results from an interaction of genetic or environmental factors, including viral infections. Other authors have reported that acute viral bronchiolitis was associated with the onset of symptoms in infants with surfactant protein $C$ mutation (a type of chllD), but rarely with NEHI. ${ }^{(14-16)}$ Other ILDs can produce symptoms in the neonatal period in full-term infants, such as surfactant dysfunction, especially of $A B C A 3$ mutations and, in some cases, of surfactant protein C mutations. ${ }^{(15,17,18)}$ Mutations in these proteins might cause clinical findings that cannot be easily differentiated from other benign forms of ILD in infants, such as NEHI.

Most of the infants in the present series did not require continuous oxygen therapy, despite the early development of symptoms and persistence of retractions. This less severe phenotypic presentation has not been described in previous series..$^{(1,14,19)}$ Recently, Lukkarinen et al. ${ }^{(20)}$ has described a series of 9 cases of $\mathrm{NEHI}$, and only 33\% of the patients presented with hypoxia. Clinical manifestations (such as difficulty in gaining weight and feeding problems) are common, and nonspecific complaints are frequently seen in various forms of chllD. 
These symptoms are probably due to respiratory distress, especially in young infants, and usually improve with age. An important clinical feature, observed in almost $70 \%$ of our patients but not previously reported, is increased anteroposterior chest diameter, suggesting an obstructive disorder. Although our patients presented with a picture suggestive of airway disease (hyperinflation on chest X-ray and increased anteroposterior diameter of the chest), chest auscultation was normal or revealed "Velcro" type crackles, consistent with ILD. During follow-up, some infants experienced progressive improvement in symptoms that evolved to complete resolution, whereas the majority of the cases showed persistent mild respiratory dysfunction. Our findings corroborate those in other series and show that NEHl is a pediatric interstitial disorder with a good prognosis and long duration. ${ }^{(1,6,14,19)} 1 \mathrm{t}$ is not known whether NEHl is a self-limited childhood disease or whether it is related to other diseases in adults, such as diffuse idiopathic pulmonary neuroendocrine cell hyperplasia..$^{(4,21)}$ A longer follow-up period is required in order to determine the natural evolution of NEHI. The most severely affected infants in our sample received systemic corticosteroids but showed no improvement in clinical response. Improvement seemed to occur with age, especially after 2 years of age, rather than as a result of a specific treatment. Because NEHI lacks inflammatory characteristics, patients are unlikely to benefit from anti-inflammatory drugs. Hence, the last patients in our series received no corticosteroid therapy.

The functional assessment of the children in our series revealed an obstructive pattern without bronchodilator response. Recently, Kerby et al. ${ }^{(22)}$ have described a pattern of significant pulmonary obstruction and air trapping in young children with a clinical and tomographic diagnosis of NEHl, confirmed or not by lung biopsy. Clinical improvement with age is likely associated with functional improvement. Studies based on larger series of NEHI patients might help clarify the relationship between initial functional severity and clinical or radiological improvement.

The histopathological findings in infants who underwent lung biopsy showed mild histological abnormalities, and immunohistochemistry showed a significant number of bombesin-positive cells, consistent with neuroendocrine cells, which is similar to the findings described in the original report. ${ }^{(1)}$ Unlike the minor changes described in the original histopathological findings, Young et al. ${ }^{(19)}$ found inflammation in plaques or pulmonary fibrosis in a
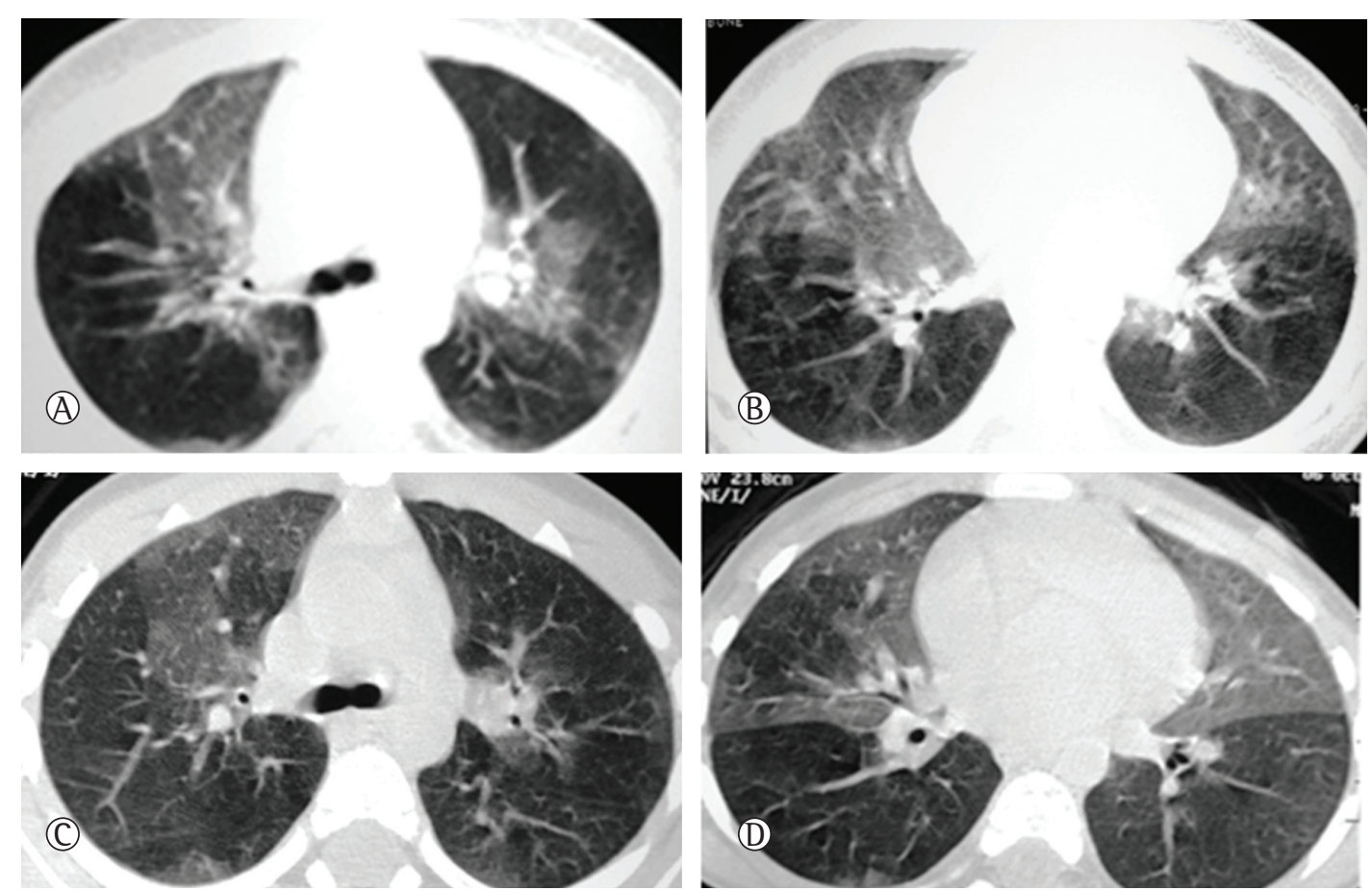

Figure 2 - In A and B, HRCT scans of a 8-month-old patient showing geographic areas of ground-glass opacities in the central zone of the upper lobes, middle lobe, and lingula. In C and D, follow-up HRCT scans of the same patient two years later showing that the findings persist, although with less intensity. 
series of infants with NEHl. In the same study, the authors examined the distribution and frequency of neuroendocrine cells in NEHl and in other lung diseases, and they demonstrated that, despite the significant prominence of neuroendocrine cells in $\mathrm{NEHl}$, the finding was not specific for the diagnosis. The extensive inter- and intrasubject variability in the number of neuroendocrine cells in typical cases of $\mathrm{NEHI}$ and the potential for overlapping with other lung diseases suggest that a clinical, radiological, and pathological correlation is required for the diagnosis of NEHl. Recently, guidelines for the histological diagnosis of NEHI have been developed. ${ }^{(23)}$

Brody et al. ${ }^{(9)}$ showed that GGO in the central regions of the lungs is a characteristic finding on chest HRCT in infants with NEHI, with a sensitivity of $78 \%$ and a specificity of $100 \%$. Five or more lobes were affected in $83 \%$ of cases in our series, and the middle lobe and the lingula were affected in all of the cases. Similarly to the findings of Brody et al. ${ }^{(9)}$, mosaic or diffuse air trapping was the second most common finding on chest HRCT. The presence of these tomographic findings in infants with symptoms suggestive of

chllD syndrome

(Persistent tachypnea of infancy, retractions, crackles, and hypoxemia)

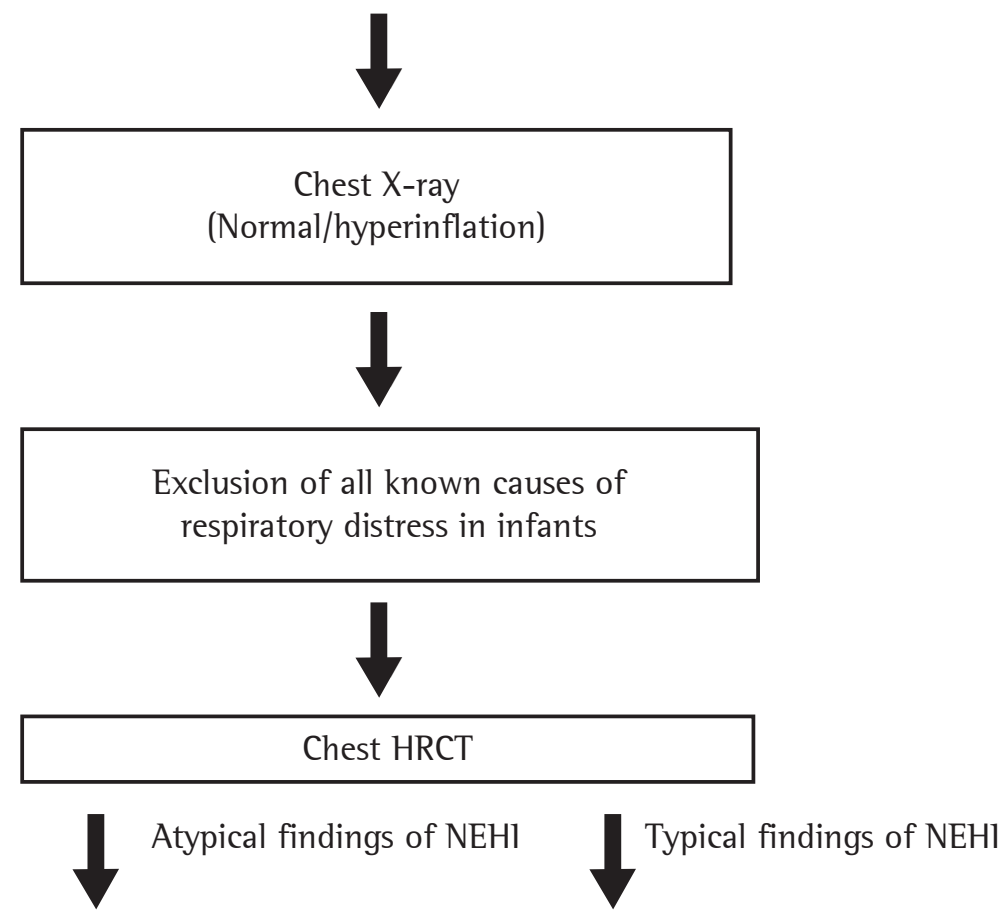

Pulmonary biopsy with

Immunohistochemistry with

bombesin antibody staining

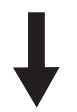

NEHI (invasive diagnosis)
Central ground-glass opacities involving at least four lung lobes (including middle lobe and lingula) + air trapping

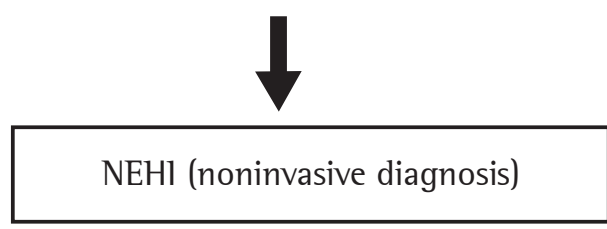

Figure 3 - Algorithm for the diagnosis of neuroendocrine cell hyperplasia of infancy (NEHI). chlLD: childhood interstitial lung disease. 
ILD has led to the establishment of a diagnosis of "NEHI syndrome". In the present series, all of the infants met the clinical and tomographic criteria for the diagnosis of NEHI, allowing us to dispense with lung biopsy in most cases.

There is still considerable discussion about the need for lung biopsy in children with probable NEHl, although most of the authors currently dispense with biopsies in typical cases of NEHI. ${ }^{(9,13,19,22,24)}$ The need for diagnostic lung biopsy in cases suspected of NEHl is currently reserved for significantly symptomatic patients or those with no characteristic clinical or tomographic findings (Figure 3).

To the best of our knowledge, no published report to date has included a description of follow-up CT scans of patients with NEHI. In most of our cases, tomographic changes persisted, although to a lesser degree, regardless of clinical improvement, age, and length of follow-up.

The present study has some limitations, including the small sample size. Despite the small number of patients included, our sample of 12 infants with NEHl might seem relatively large for a single institution, considering the rarity of the disease. Another limitation was the lack of a radiological follow-up protocol. In order to avoid unnecessary radiation, radiological protocols for NEHl should be standardized. The lack of functional evaluation in infants was another limitation of our study, given that the characteristic functional pattern observed in the disease (significant pulmonary obstruction and air trapping) could be added to the typical tomographic findings in an attempt to corroborate the noninvasive diagnosis of NEHI.

In conclusion, we suggest that NEHI can be diagnosed on the basis of clinical and radiological findings. The presence of persistent tachypnea, retractions, crackles, and low oxygen saturation in a infant without auscultatory findings suggestive of airway disease, as well as tomographic findings of GGO in the central regions of the lungs, involving at least four lobes, especially the middle lobe and lingula, associated with air trapping, is highly suggestive of NEHl. In such circumstances, lung biopsy should be avoided.

\section{References}

1. Deterding RR, Pye C, Fan LL, Langston C. Persistent tachypnea of infancy is associated with neuroendocrine cell hyperplasia. Pediatr Pulmonol. 2005;40(2):157-65. http://dx.doi.org/10.1002/ppul.20243 PMid:15965897
2. Deterding RR, Fan LL, Morton R, Hay TC, Langston C. Persistent tachypnea of infancy (PTI)--a new entity. Pediatr Pulmonol. 2001;Suppl 23:72-3. PMid:11886155

3. Cutz E, Yeger H, Pan J. Pulmonary neuroendocrine cell system in pediatric lung disease-recent advances. Pediatr Dev Pathol. 2007;10(6):419-35. http://dx.doi. org/10.2350/07-04-0267.1 PMid:18001162

4. Coletta EN, Voss LR, Lima MS, Arakaki JS, Câmara J, D'Andretta Neto C, et al. Diffuse idiopathic pulmonary neuroendocrine cell hyperplasia accompanied by airflow obstruction. J Bras Pneumol. 2009;35(5):489-94. PMid:19547861

5. Fan LL, Deterding RR, Langston C. Pediatric interstitial lung disease revisited. Pediatr Pulmonol. 2004;38(5):369-78. http://dx.doi.org/10.1002/ppul.20114 PMid:15376335

6. Deutsch GH, Young LR, Deterding RR, Fan LL, Dell SD, Bean JA, et al. Diffuse lung disease in young children: application of a novel classification scheme. Am J Respir Crit Care Med. 2007;176(11):1120-8. http:// dx.doi.org/10.1164/rccm.200703-3930C PMid:17885266 PMCid:PMC2176101

7. Brody AS. Imaging considerations: interstitial lung disease in children. Radiol Clin North Am. 2005;43(2):391-403. http://dx.doi.org/10.1016/j.rcl.2004.12.002 PMid:15737375

8. Brody AS, Crotty EJ. Neuroendocrine cell hyperplasia of infancy (NEHI). Pediatr Radiol. 2006;36(12):1328. http:// dx.doi.org/10.1007/s00247-006-0302-3 PMid:16957891

9. Brody AS, Guillerman RP, Hay TC, Wagner BD, Young LR, Deutsch GH, et al. Neuroendocrine cell hyperplasia of infancy: diagnosis with high-resolution CT. AJR Am J Roentgenol. 2010;194(1):238-44. http://dx.doi. org/10.2214/AJR.09.2743 PMid:20028928

10. Deterding R. Evaluating infants and children with interstitial lung disease. Semin Respir Crit Care Med. 2007;28(3):333-41. http://dx.doi. org/10.1055/s-2007-981654 PMid:17562503

11. Lucaya J, García-Pe-a P, Herrera L, Enríquez G, Piqueras J. Expiratory chest CT in children. AJR Am J Roentgenol. 2000;174(1):235-41. http://dx.doi.org/10.2214/ ajr.174.1.1740235 PMid:10628485

12. Hansell DM, Bankier AA, MacMahon H, Mcloud TC, Müller NL, Remy J. Fleischner Society: glossary of terms for thoracic imaging. Radiology. 2008;246(3):697-722. http:// dx.doi.org/10.1148/radiol.2462070712 PMid:18195376

13. Deterding RR. Infants and young children with children's interstitial lung disease. Pediatr Allergy lmmunol Pulmonol. 2010;23(1):25-31. http://dx.doi.org/10.1089/ped.2010.0011 PMid:22332029 PMCid:PMC3269220

14. Popler J, Gower WA, Mogayzel PJ Jr, Nogee LM, Langston C, Wilson AC, et al. Familial neuroendocrine cell hyperplasia of infancy. Pediatr Pulmonol. 2010;45(8):749-55. http:// dx.doi.org/10.1002/ppul.21219 PMid:20623780

15. Thouvenin G, Abou Taam R, Flamein F, Guillot L, Le Bourgeois M, Reix P, et al. Characteristics of disorders associated with genetic mutations of surfactant protein C. Arch Dis Child. 2010;95(6):449-54. http://dx.doi. org/10.1136/adc.2009.171553 PMid:20403820

16. Mechri M, Epaud R, Emond S, Coulomb A, Jaubert F, Tarrant A, et al Surfactant protein C gene (SFTPC) mutation-associated lung disease: high-resolution computed tomography (HRCT) findings and its relation to histological analysis. Pediatr Pulmonol. 2010;45(10):1021-9. http://dx.doi.org/10.1002/ppul.21289 PMid:20658481 
17. Doan ML, Guillerman RP, Dishop MK, Nogee LM, Langston C, Mallory GB, et al. Clinical, radiological and pathological features of ABCA3 mutations in children. Thorax. 2008;63(4):366-73. http://dx.doi.org/10.1136/ thx.2007.083766 PMid:18024538

18. Nogee LM. Genetic Basis of Children's Interstitial Lung Disease. Pediatr Allergy Immunol Pulmonol. 2010;23(1):15-24. http://dx.doi.org/10.1089/ped.2009.0024 PMid:22087432 PMCid:PMC3207222

19. Young LR, Brody AS, Inge TH, Acton JD, Bokulic RE, Langston $\mathrm{C}$, et al. Neuroendocrine cell distribution and frequency distinguish neuroendocrine cell hyperplasia of infancy from other pulmonary disorders. Chest. 2011;139(5):1060-71. http://dx.doi.org/10.1378/chest.101304 PMid:20884725

20. Lukkarinen H, Pelkonen A, Lohi J, Malmström K, Malmberg $\mathrm{LP}$, Kajosaari M, et al. Neuroendocrine cell hyperplasia of infancy: a prospective follow-up of nine children. Arch Dis Child. 2013;98(2):141-4. http://dx.doi.org/10.1136/ archdischild-2012-302115 PMid:23161905
21. Davies SJ, Gosney JR, Hansell DM, Wells AU, du Bois RM, Burke MM, et al. Diffuse idiopathic pulmonary neuroendocrine cell hyperplasia: an under-recognised spectrum of disease. Thorax. 2007;62(3):248-52. http:// dx.doi.org/10.1136/thx.2006.063065 PMid:17099078 PMCid:PMC2117154

22. Kerby GS, Wagner BD, Popler J, Hay TC, Kopecky C, Wilcox SL, et al. Abnormal infant pulmonary function in young children with neuroendocrine cell hyperplasia of infancy. Pediatr Pulmonol. 2013;48(10):1008-15. http://dx.doi.org/10.1002/ppul.22718 PMid:23169677

23. Dishop MK. Diagnostic pathology of diffuse lung disease in children. Pediatr Allergy Immunol Pulmonol. 2010;23(1):69-85. http://dx.doi.org/10.1089/ped.2010.0007 PMid:22332032 PMCid:PMC3269262

24. Guillerman RP. Imaging of Childhood Interstitial Lung Disease. Pediatr Allergy Immunol Pulmonol. 2010;23(1):43-68. http://dx.doi.org/10.1089/ped.2010.0010 PMid:22332031 PMCid:PMC3269227

\section{About the authors}

\section{Vivianne Calheiros Chaves Gomes}

Pediatric Pulmonologist. Hospital Infantil Albert Sabin, Fortaleza, Brazil.

\section{Mara Cristina Coelho Silva}

Pediatric Pulmonologist. Hospital Infantil Albert Sabin, Fortaleza, Brazil.

\section{José Holanda Maia Filho}

Radiologist. Hospital Infantil Albert Sabin, Fortaleza, Brazil.

\section{Pedro Daltro}

Doctoral Student in Radiology. Federal University of Rio de Janeiro, Rio de Janeiro, Brazil.

\section{Simone Gusmão Ramos}

Pathologist. University of São Paulo at Ribeirão Preto School of Medicine, Ribeirão Preto, Brazil.

\section{Alan S. Brody}

Radiologist. Cincinnati Children's Hospital, Cincinnati (OH) USA.

\section{Edson Marchiori}

Associate Professor of Radiology. Federal University of Rio de Janeiro, Rio de Janeiro, Brazil. 